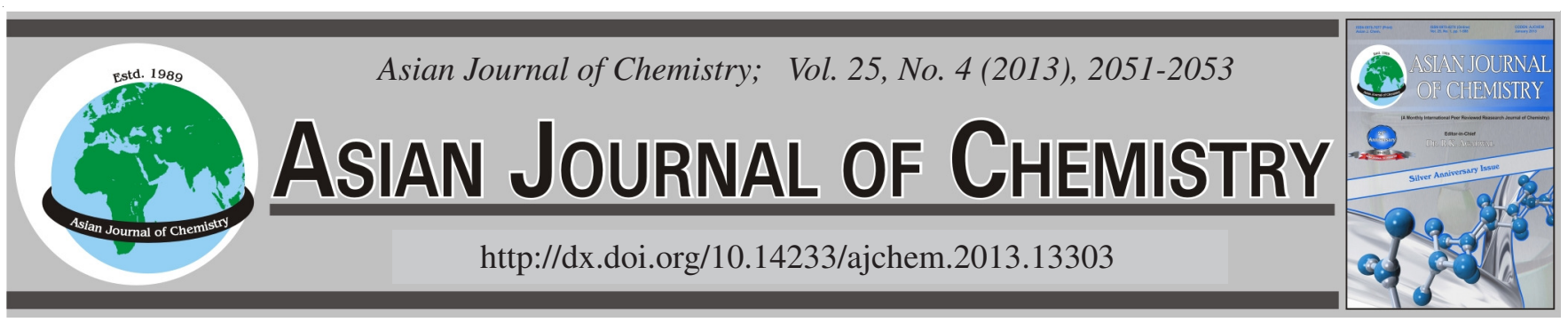

\title{
DFT Studies on Optimized Geometries for Thiazole Derivatives
}

Farshid Salimi", Hajar Sahebalzamani, Elaheh Hezhabri, Bita Minaei and Masoumeh Hajhosseini

Department of Chemistry, Faculty of Science, Ardabil Branch, Islamic Azad University, Ardabil, Iran

*Corresponding author: Fax: +98 451 7727799; Tel: +98 451 7727797; E-mail: salimif@yahoo.com

(Received: 21 December 2011;

Accepted: 12 October 2012)

AJC-12277

\begin{abstract}
The molecular geometry and energies of $N, N^{\prime}$-bis-(2-thiazol-yl)methylenediamine (1) in the ground state are calculated by using the density functional (HCTH/PBE1PBE) methods with 6-31G* basis sets. The calculated HOMO and LUMO energies also confirm that charge transfer occurs within the molecule. The geometries and energies obtained from HCTH/PBE1PBE/6-31G* calculations are in good agreement with the experimental data.

Key Words: $N$, $N^{\prime}$-bis-(2-thiazol-yl)methylenediamine, HCTH, DFT, HOMO, LOMO.
\end{abstract}

\section{INTRODUCTION}

2-Aminothiazole derivatives are widely used as pharmaceuticals. For example, talipexol ${ }^{1}$ and pramipexole ${ }^{2}$ with a 2-aminothiazole moiety are used as antiparkinsonian drugs and dopamine agonists; tigemonam ${ }^{3}$ is an antibacterial drug and amthamine ${ }^{4}$ is known as an antiasthmatic one. It is also known that heterocyclic compounds with free amino groups may exhibit teratogenic and mutagenic properties because of their ability to form non-covalent complexes with DNA ${ }^{5,6}$. The 2-aminothiazole derivatives with an acylated amino group may be of interest as potentially less toxic drugs with a wide variety of pharmacological activities. A number of publications have described the synthesis of 2-aminothiazoles, $\mathrm{N}$-acylated with aliphatic $^{7-11}$, aromatic ${ }^{7,8,10}$ and dicarboxylic acids ${ }^{10,12-16}$. The importance of such derivatives is due to their biological properties; for example, some of them show significant bacteriostatic $^{7}$, tuberculostatic ${ }^{8}$, hypoglycemic, antiinflammatory, diuretic and fungicidal activities ${ }^{10}$ and some of them are useful for treating of asthma ${ }^{14}$.

In this study, molecular geometry, optimized parameters and energies are computed and the performance of the computational methods for density functional theory (HCTH/ PBE1PBE) levels at 6-31G* basis sets are compared.

The HOMO represents the ability to donate an electron, LUMO as an electron acceptor represents the ability to obtain an electron the HOMO and LUMO energy calculated by HCTH/PBE1PBE at 6-31G* method.

\section{EXPERIMENTAL}

All calculations were performed using the Gaussian 98 package of program ${ }^{17}$ on a Windows-XP operating PC. The molecular structure of the title compound in the ground state is computed by performing both HCTH and PBE1PBE with 6-31G* basis sets.

\section{RESULTS AND DISCUSSION}

The optimized molecular structure of title molecule is obtained from Gaussian 98 and GaussView 3.0 programs are shown in the Fig. 1.

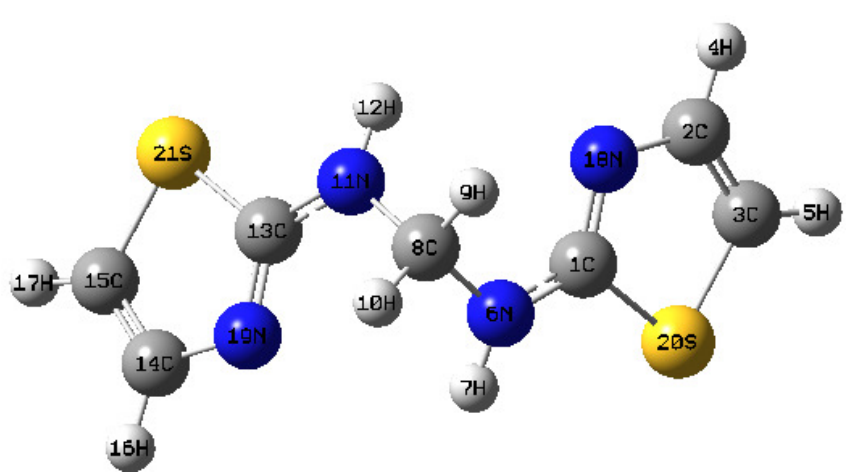

Fig. 1. Numbering system adopted in the study for (1) by using DFT/6$31 \mathrm{G}^{*}$

Computational (theoretical) calculations energy differences for the compound (1) were determined by optimizing the geometry at various computational levels. Comparison of the energies at the HCTH/6-31G*, PBE1PBE/6-31G* levels listed in Table-1 shows the differences in the energies.

The optimized structural parameters of compound (1) calculated by density functional theory HCTH/PBE1PBE levels with the standard 6-31G* basis set are listed in Table-2. 
Bond lengths of all pairs decrease in going from $\mathrm{HCTH} / 6-$ $31 \mathrm{G}^{*}$ to PBE1PBE/6-31G*. The comparative graphs of bond lengths and bond angles of title molecule are presented in Figs. 2 and 3 respectively.

TABLE-1

THEORETICALLY COMPUTED ENERGIES (a.u.), ZERO-POINT VIBRATIONAL ENERGIES $\left(\mathrm{kcal} \mathrm{mol}^{-1}\right)$, ROTATIONAL CONSTANTS (GHz), ENTROPIES ( $\mathrm{cal} \mathrm{mol}^{-1} \mathrm{~K}^{-1}$ ) FOR COMPOUND OF (1) AT THE HCTH/PBE1PBE/6-31G*

\begin{tabular}{lcc}
\hline Parameters & HCTH $\left(6-31 \mathrm{G}^{*}\right)$ & PBE1PBE(6-31G*) \\
\hline Total energy & -1286.7375 & -1285.8656 \\
Zero-point energy & 96.3816 & 98.4072 \\
Rotational constants & 1.4584 & 1.3943 \\
& 0.2775 & 0.2975 \\
& 0.2672 & 0.2882 \\
Entropy total & 113.889 & 100.101 \\
Translational & 41.958 & 41.629 \\
Rotational & 32.363 & 31.477 \\
Vibrational & 39.568 & 25.618 \\
\hline
\end{tabular}

\begin{tabular}{|c|c|c|}
\hline \multicolumn{3}{|c|}{$\begin{array}{c}\text { TABLE-2 } \\
\text { GEOMETRICAL PARAMETERS OPTIMIZED OF } \\
\text { COMPOUND (1), BOND LENGTH ( } \AA \text { ) AND } \\
\text { ANGLE ( }() \text { AT THE HCTH/PBE1PBE/6-31G* }\end{array}$} \\
\hline Bond lengths & HCTH & PBE1PBE \\
\hline & \multicolumn{2}{|c|}{$6-31 G^{*}$} \\
\hline $\mathrm{C}(1) \mathrm{N}(18)$ & 1.314 & 1.311 \\
\hline$C(1) S(20)$ & 1.834 & 1.818 \\
\hline $\mathrm{C}(1) \mathrm{N}(6)$ & 1.361 & 1.357 \\
\hline $\mathrm{N}(18) \mathrm{C}(2)$ & 1.391 & 1.392 \\
\hline$S(20) C(3)$ & 1.801 & 1.801 \\
\hline $\mathrm{C}(2) \mathrm{C}(3)$ & 1.362 & 1.356 \\
\hline $\mathrm{N}(6) \mathrm{C}(8)$ & 1.456 & 1.451 \\
\hline $\mathrm{C}(8) \mathrm{N}(11)$ & 1.456 & 1.451 \\
\hline $\mathrm{N}(11) \mathrm{C}(13)$ & 1.361 & 1.357 \\
\hline $\mathrm{C}(13) \mathrm{N}(19)$ & 1.314 & 1.311 \\
\hline $\mathrm{C}(13) \mathrm{S}(21)$ & 1.834 & 1.818 \\
\hline $\mathrm{N}(19) \mathrm{C}(14)$ & 1.391 & 1.392 \\
\hline$S(21) C(15)$ & 1.801 & 1.801 \\
\hline$C(14) C(15)$ & 1.362 & 1.356 \\
\hline $\mathrm{N}(19) \mathrm{C}(13) \mathrm{S}(21)$ & 114.12 & 114.36 \\
\hline $\mathrm{N}(19) \mathrm{C}(13) \mathrm{N}(11)$ & 124.90 & 124.04 \\
\hline$S(21) C(13) N(11)$ & 120.94 & 121.57 \\
\hline $\mathrm{C}(13) \mathrm{N}(19) \mathrm{C}(14)$ & 111.83 & 111.70 \\
\hline$C(13) S(21) C(15)$ & 86.74 & 86.92 \\
\hline $\mathrm{N}(19) \mathrm{C}(14) \mathrm{C}(15)$ & 116.91 & 116.80 \\
\hline$S(21) C(15) C(14)$ & 110.37 & 110.18 \\
\hline $\mathrm{N}(11) \mathrm{C}(8) \mathrm{N}(6)$ & 114.84 & 113.74 \\
\hline $\mathrm{N}(6) \mathrm{C}(1) \mathrm{S}(20)$ & 121.94 & 121.57 \\
\hline $\mathrm{N}(6) \mathrm{C}(1) \mathrm{N}(18)$ & 124.90 & 124.04 \\
\hline $\mathrm{S}(20) \mathrm{C}(1) \mathrm{N}(18)$ & 114.12 & 114.36 \\
\hline $\mathrm{C}(1) \mathrm{N}(18) \mathrm{C}(2)$ & 111.82 & 111.70 \\
\hline $\mathrm{C}(1) \mathrm{S}(20) \mathrm{C}(3)$ & 86.74 & 86.92 \\
\hline $\mathrm{N}(18) \mathrm{C}(2) \mathrm{C}(3)$ & 116.91 & 116.80 \\
\hline $\mathrm{S}(20) \mathrm{C}(3) \mathrm{C}(2)$ & 110.37 & 110.18 \\
\hline
\end{tabular}

The bond length C1-N6 is 1.361 and 1.357 at HCTH/6$31 \mathrm{G}^{*}$ and PBE1PBE/6-31G* level. Also C8-N6 is 1.456 and 1.451 at $\mathrm{HCTH} / 6-31 \mathrm{G}^{*}$ and PBE1PBE/6-31G* level. Hence in the case of DFT calculation, the value of bond length C8N6 is $0.095 \AA$ at HCTH/6-31G* level and $0.094 \AA$ at PBE1PBE/6-31G* greater than bond length C1-N6. This increase of bond length is exactly may be due to the single $(\mathrm{C}-\mathrm{N})$ and double $(\mathrm{C}=\mathrm{N})$ bond lengths.

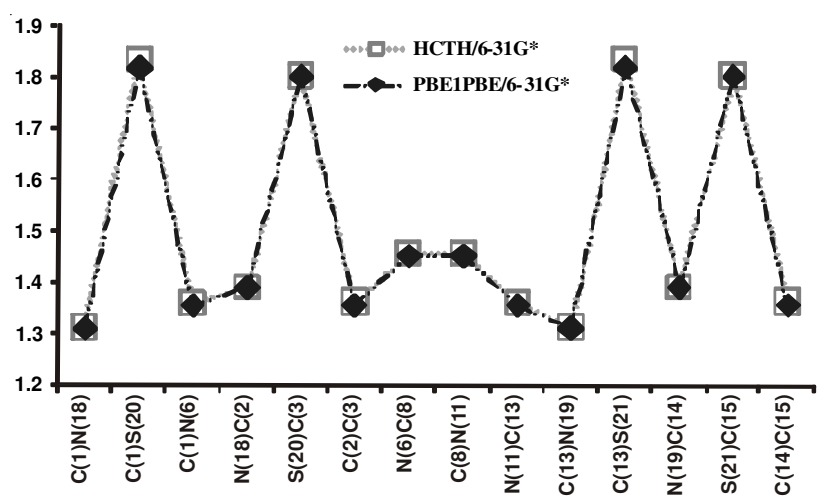

Fig. 2. Bond length differences between theoretical [DFT] approaches

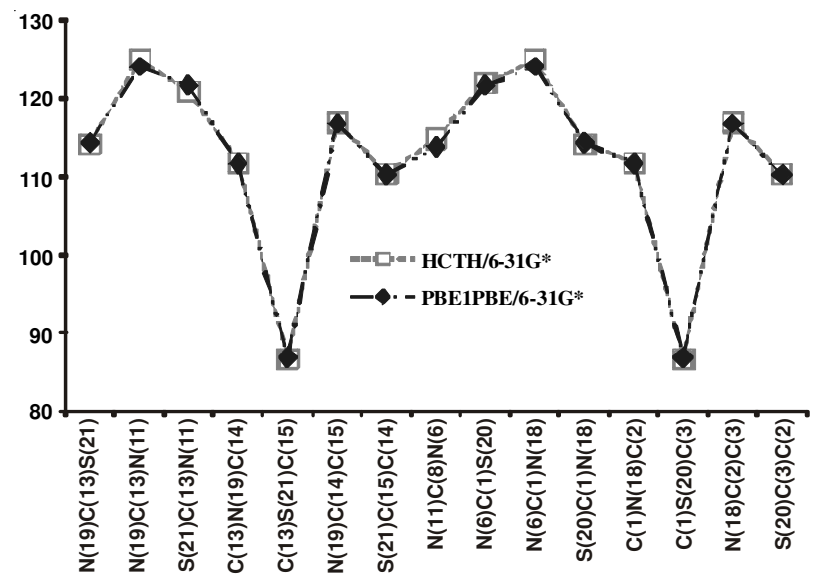

Fig. 3. Bond angle differences between theoretical [DFT] approaches

The HOMO represents the ability to donate an electron, LUMO as an electron acceptor represents the ability to obtain an electron the HOMO and LUMO energy calculated by HCTH/PBE1PBE levels with the 6-31G* basis set Fig. 4. This electronic absorption corresponds to the transition from the ground to the first excited state and is mainly described by one electron excitation from the highest occupied molecular or orbital (LUMO). The HOMO is located over the group, the $\mathrm{HOMO} \rightarrow$ LUMO transition implies an electron density transfer to ring from chlorine and partially from ring.
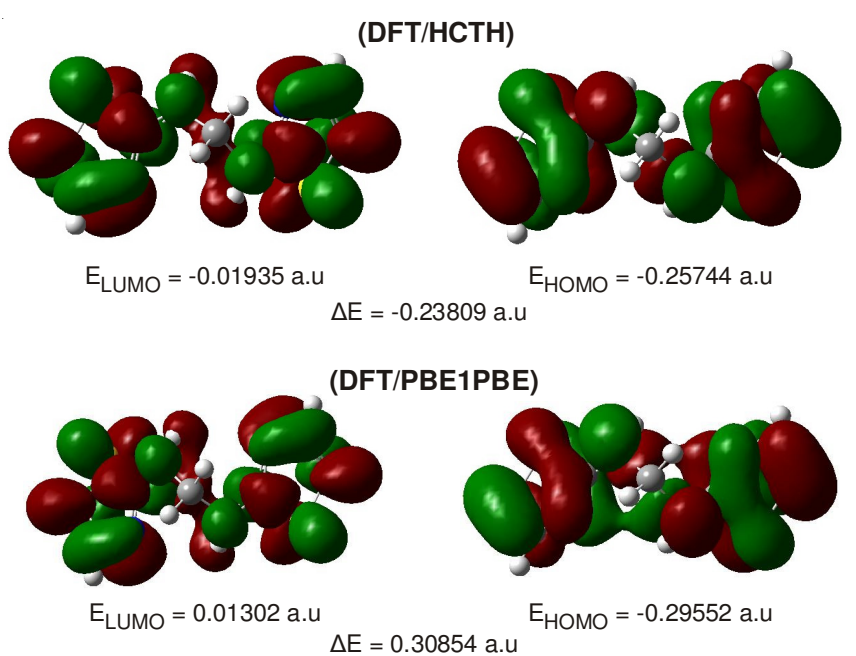

Fig. 4. Atomic orbital compositions of the frontier molecular orbital for compound (1) 


\section{Conclusion}

Density functional theory (HCTH/PBE1PBE) levels at 6-31G* basis sets calculations were carried out on $N, N^{\prime}-$ bis-(2-thiazol-yl)methylenediamine. The HCTH and PBE1PBE method with the 6-31G* basis set have been used to determine the ground state geometries, energies of compound (1).

\section{REFERENCES}

1. C. Pifl, L. Pichler, W. Kobinger and O. Hornykiewicz, Eur. J. Pharmacol., 153, 33 (1988)

2. C.S. Schneider and J. Mierau, J. Med. Chem., 30, 494 (1987).

3. J.M. Clark, S.J. Olsen, D.S. Weinberg, M. Dalvi, R.R. Whitney, D.P. Bonner and R.B. Sykes, Antimicrob. Agents Chemother., 31, 226 (1987)

4. J.C. Eriks, H. Vandergoot, G.J. Sterk and H. Timmerman, J. Med. Chem., 35, 3239 (1992)

5. C.E. Voogd, J.J. Van der Stel and H.W. Verharen, Mutat. Res., 118, 153 (1983).

6. J.C. Greenaway, A.G. Fantel and M.R. Juchau, Toxicol. Appl. Pharmacol., 82, 307 (1986).

7. A.L. Mndzhoyan, V.G. Afrikyan and Izv AN Armyan. SSR Ser. Khim. Nauk, 10, 143 (1957).

8. A.L. Mndzhoyan, N.A. Apoyan, L.D. Zhuruli and Yu. Zh. Ter-Zakharyan, Biol. Svoistva Khim. Soedin., Akad. Nauk Arm. SSR, Inst. Tonkoi Organ. Khim., 219 (1962).
9. A.L. Mndzhoyan, M.A. Kaldrikyan, R.G. Melik-Ogandzhanyan and A.A. Aroyan, Azerb. Khim. Zh., 20, 51 (1967).

10. V.P. Chernykh, V.I. Kabachnyi, V.A. Shapovalova, L.A. Porokhnyak and V.N. Savchenko, Khim.-Pharm. Zh., 23, 825 (1989).

11. H.-L. Liu and Z.C. Li, Molecules, 5, 1063 (2000).

12. A.L. Mndzhoyan and A.A. Grigoryan, Docl. AN Armyan. SSR, 22, 215 (1956).

13. R.V. Ghate and B.V.I. Bhide, J. Univ. Bombay, Sci., 25, 17 (1957).

14. H. Cousse and G. Mouzin, U.S. Patent 4246271 (1981).

15. P. Lesimple and D.C.H. Bigg, Synthesis, 763 (1991).

16. A.V. Dolzhenko, N.V. Kolotova, V.O. Koz'minykh, M.V. Vasilyuk, V.P. Kotegov, G.N. Novoselova, B. Ya. Syropyatov and M.I. Vakhrin, Pharm. Chem. J., 37, 149 (2003).

17. M.J. Frisch, G.W. Trucks, H.B. Schlegel, G.E. Scuseria, M.A. Robb, J.R. Cheeseman, V.G. Zakrzewski, J.A. Montgomery Jr., R.E. Stratmann, J.C. Burant, S. Dapprich, J.M. Millam, A.D. Daniels, K.N. Kudin, M.C. Strain, O. Farkas, J. Tomasi, V. Barone, M. Cossi, R. Cammi, B. Mennucci, C. Pomelti, C. Adamo, S. Clifford, J. Ochterski, G.A. Petersson, P.Y. Ayala, Q. Cui, K. MoroKuma, D.K. Malick, A.D. Rabuck, K. Raghavachari, J.B. Foresman, J. Cioslowski, J.V. Ortiz, B.B. Stefanov, G. Liu, A. Liashenko, P. Piskorz, I. Komaromi, R. Gomperts, R.L. Martin, D.J. Fox, T. Keith, M.A. Al-Laham, C.Y. Peng, A. Nanayakkara, C. Gonzalez, M. Challacombe, P.M.W. Gill, B. Johnson, W. Chen, M.W. Wong, J.L. Andres, M. Head-Gordon, E.S. Replogle, J.A. Pople, GAUSSIAN 98 (Revision A. 3) Gaussian Inc., Pittsburgh, PA, USA (1998). 